\title{
A cross-sectional study of intestinal parasitic infections in a rural district of west China
}

\author{
Ning Tang BSc MPH, Nian Ji Luo HC
}

N Tang, NJ Luo. A cross-sectional study of intestinal parasitic enfections in a rural district of west China. Can J Infect Dis 2003;14(3):159-162

BACKGROUND: Parasitic infections are widespread in rural areas of West China. The remote and humid environment, traditional ways of life, contaminated potable water and limited health services all contribute to the transmission and persistence of fecal parasites.

OBJECTIVE: To describe the prevalence of intestinal parasitic infections in an area of West China, including its associations with demographic variables.

METHODS: Single fecal specimens were collected using a previously validated kit. Parasites were detected microscopically by iodinestained smear, modified Kato-Katz thick smear, simple saline smear, test tube filter paper culture and adhesive cellophane tape anal swab. RESULTS: The prevalence of enteric parasites in the population was $51.7 \%$. The proportion of individuals infected with one parasite was $36.5 \%$, two parasites $12.7 \%$, three parasites $3.0 \%$ and four parasites $0.08 \%$. Parasites identified included Ascaris lumbricoides in 41.4\% of all individuals tested, Ancylostoma duodenale in $17.7 \%$, Trichurias trichuria in $8.25 \%$, Enterobius vermicularis in $0.43 \%$, Blastocystis hominis in 1.37\%, Entamoeba coli in $0.47 \%$, Entamoeba histolytica in $0.16 \%$, Giardia lamblia in $0.04 \%$, Strongyloides stercoralis in $0.04 \%$ and Clonorchis sinensis in $0.04 \%$. The prevalence was significantly increased in women, people aged 15 to 19 years and over 80 years, the rural farm population, farmers, preschool and primary school groups, residents of a hilly rather than mountainous or plains terrain, and in intermediate income groups. The prevalence was significantly negatively associated with educational level, but not with age or income.

CONCLUSIONS: This study supports the use of simple fecal examinations to monitor the parasite burden in rural areas of developing countries. Enteric parasites remain common in this population in rural China.

Key Words: Amoebiasis; Ancylostoma duodenale; Ascaris lumbriocoides; Clonorchiasis, Fecal parasites; Giardiasis; Rural China

\section{Étude transversale des infections parasitiques intestinales dans un district rural de l'ouest de la Chine}

HISTORIQUE: Les infections parasitiques sont généralisées dans les régions rurales de l'ouest de la Chine. Le milieu éloigné et humide, les modes de vie traditionnels, l'eau potable contaminée et les services de santé limités contribuent tous à la transmission et à la persistance des parasites fécaux.

OBJECTIF: Décrire la prévalence des infections parasitiques intestinales dans une région de l'ouest de la Chine, y compris ses associations avec leurs variables démographiques.

MÉTHODOLOGIE: Un seul prélèvement fécal a été colligé au moyen d'une trousse déjà validée. Les parasites ont été décelés au microscope par frottis à l'iode, méthode de Kato, simple frottis de sérum physiologique, culture de papier filtre en éprouvette et écouvillonnage anal par ruban adhésif de cellophane.

RÉSULTATS: La prévalence de parasites entériques dans la population s'élevait à $51,7 \%$. La proportion de personnes infectées par un parasite était de 36,5\%, par deux parasites, de $12,7 \%$, par trois parasites, de 3,0\%, et par quatre parasites, de $0,08 \%$. Les parasites décelés étaient l'Ascaris lumbricoides chez $45,4 \%$ de tous les individus examinés, l'Ancylostoma duodenale chez 17,7\% d'entre eux, le Trichurias trichuria chez 8,25\%, l'Enterobius vernicularis chez 0,43\%, le Blastocystic hominis chez 1,37\%, l'Entamoeba coli chez 0,47\%, l'Entamoeba histolytica chez 0,16\%, le Giardia lamblia chez 0,04\%, le Strongyloides stercoralis chez 0,04 \% et le Clonorchis sinensis chez $0,04 \%$. La prévalence étaient beaucoup plus élevée chez les femmes, les adolescents de 15 à 19 ans et les personnes de plus de 80 ans, dans la population agricole rurale, chez les fermiers, les groupes d'âge préscolaire et primaire, les habitants de régions vallonnées plutôt que montagneuses ou des plaines et les groupes à revenu moyen. De façon appréciable, la prévalence était associée négativement au niveau d'instruction, mais non à l'âge ou au revenu.

CONCLUSIONS: La présente étude appuie le recours à des examens fécaux simples pour évaluer le fardeau des parasites dans les régions rurales des pays en voie de développement. Les parasites entériques demeurent courants au sein de cette population de la Chine rurale.
$\mathrm{T}^{\mathrm{s}}$ he mortality and health problems parasitic diseases cause retard social and economic development in low-income countries (1). Parasitic diseases are also of concern in developed countries because of travel, immigration and an increasing population of immunocompromised people $(2,3)$. Previous studies have reported a high prevalence of intestinal parasites in rural China $(4,5)$, reaching $62.6 \%(95 \% \mathrm{CI} 17.5 \%$ to $94.7 \%)$ in some areas (4). Trends observed have included a

Health and Anti-epidemic station (Centre for Disease Control and Prevention), Beibei, Chongqing, China

Correspondence and reprints: Mr Ning Tang, present address in Australia:1/13 Gwynne Street, Gwynneville, Wollongong, New South Wales, Australia, 2500. Telephone (0061 2) 42253790, e-mail nt92@uow.edu.au. Permanent address in China: Health and Anti-epidemic Station (Centre for Disease Control and Prevention), Beibei, Chongqing, China, 400700. Telephone (001186 23) 68862799, 68863569, fax (001186 23)68862799, e-mail nt920000@yahoo.com 
TABLE 1A

Infectious rates of different parasitic species in Beibei, China

\begin{tabular}{|c|c|c|c|c|c|c|}
\hline \multirow[b]{2}{*}{$\begin{array}{l}\text { Sampled areas } \\
\text { (towns or } \\
\text { communities) }\end{array}$} & \multirow[b]{2}{*}{$\begin{array}{c}\text { Tested } \\
\text { population } \\
\text { (participants) }\end{array}$} & \multirow[b]{2}{*}{$\begin{array}{l}\text { Roundworm } \\
\text { (Ascarid: Ascaris } \\
\text { lumbricoides) }\end{array}$} & \multirow[b]{2}{*}{$\begin{array}{c}\text { Hookworm } \\
\text { (Ancylostoma duodenale } \\
\text { and Necator americanus) }\end{array}$} & \multicolumn{2}{|c|}{ Number positive (\%) } & \multirow[b]{2}{*}{$\begin{array}{c}\text { Blastocystis } \\
\text { hominis }\end{array}$} \\
\hline & & & & $\begin{array}{l}\text { Whipworm } \\
\text { (Trichuris } \\
\text { trichuria) }\end{array}$ & $\begin{array}{c}\text { Pinworm } \\
\text { (Enterobius } \\
\text { vermicularis) }\end{array}$ & \\
\hline Xiema (rural) & 506 & $319(63.04)$ & $281(55.53)$ & $130(25.69)$ & $8(1.58)$ & $15(2.96)$ \\
\hline Daijia (rural) & 510 & $236(46.28)$ & 79 (15.49) & $21(4.12)$ & $0(0)$ & $8(1.57)$ \\
\hline Caijia (rural) & 515 & $150(29.13)$ & $40(7.77)$ & $31(6.02)$ & $1(0.19)$ & $0(0)$ \\
\hline Chengjiang (rural) & 514 & $254(49.42)$ & $50(9.73)$ & $16(3.11)$ & $1(0.19)$ & $19(3.70)$ \\
\hline Urban & 513 & $10(119.69)$ & $3(0.59)$ & $13(2.53)$ & $1(0.20)$ & $3(0.59)$ \\
\hline Total & 2558 & $1060(41.44)$ & $453(17.71)$ & $211(8.252)$ & $11(0.43)$ & $35(1.37)$ \\
\hline
\end{tabular}

Data continued in Table 1B (below)

TABLE 1B

Infectious rates of different parasitic species in Beibei, China

\begin{tabular}{|c|c|c|c|c|c|c|}
\hline \multirow[b]{2}{*}{$\begin{array}{l}\text { Sampled areas } \\
\text { (towns or } \\
\text { communities) }\end{array}$} & \multirow[b]{2}{*}{$\begin{array}{c}\text { Tested } \\
\text { population } \\
\text { (participants) }\end{array}$} & \multirow[b]{2}{*}{$\begin{array}{c}\text { Entamoeba } \\
\text { coli }\end{array}$} & \multicolumn{4}{|c|}{ Number positive (\%) } \\
\hline & & & $\begin{array}{c}\text { Entamoeba } \\
\text { histolytica }\end{array}$ & $\begin{array}{l}\text { Giardia } \\
\text { lamblia }\end{array}$ & $\begin{array}{l}\text { Strongyloides } \\
\text { stercoroliis }\end{array}$ & $\begin{array}{l}\text { Clonorchis } \\
\text { sinensisas }\end{array}$ \\
\hline Xiema (rural) & 506 & $10(1.98)$ & $2(0.40)$ & $1(0.20)$ & $1(0.20)$ & $1(0.20)$ \\
\hline Daija (rural) & 510 & $0(0)$ & $0(0)$ & $0(0)$ & $0(0)$ & $0(0)$ \\
\hline Caijia (rural) & 515 & $0(0)$ & $0(0)$ & $0(0)$ & $0(0)$ & $0(0)$ \\
\hline Chengjiang (rural) & 514 & $0(0)$ & $0(0)$ & $0(0)$ & $0(0)$ & $0(0)$ \\
\hline Urban & 513 & $2(0.39)$ & $2(0.39)$ & $0(9)$ & $0(0)$ & $0(0)$ \\
\hline Total & 2558 & $12(0.47)$ & $4(0.16)$ & $1(0.04)$ & $1(0.04)$ & $1(0.04)$ \\
\hline
\end{tabular}

Data continued from Table $1 A$ (above)

decrease in Entamoeba histolytica, Fasciolopsis buski and soiltransmitted helminths, and an increase in food-transmitted parasitic diseases including trichinosis, Clonorchiasis, oriental lung fluke, cysticercosis, and hydatidosis (4). The present study describes the prevalence and characteristics of parasitic infestation in a rural district of western China, including our experience with a simple stool collection tool.

Study population

\section{METHODS}

Beibei district has a population of 400,000 people, with one large urban area. For the present study, four rural quadrants were designated by East, West, South, and North coordinates, each including residents of different economic levels (high, intermediate and low). In each of the five areas (four rural and one urban), 500 to 550 people were randomly sampled. The total population that was approached to participate included 2644 people.

Ethics approval was obtained from town governments and the Beibei health bureau before the survey. All participants in the sample were assured of confidentiality, and advised that their participation was voluntary and that specimens would not be linked to individual identifiers. Each participant completed a short questionnaire that collected information including their residential area, sex, age, occupation and educational level. This information was linked by study number to the stool specimen and used only for analysis in the present study.

\section{Laboratory methods}

Each participant was provided with a standard fecal collection bag labelled with the participant's code and containing a dry plastic bag and a bamboo spike. Approximately $10 \mathrm{~g}$ of each participant's stool were collected and delivered to the laboratory within one day of collection. About $100 \mathrm{mg}$ were filtered for the parasitological evaluation and 5 to $10 \mathrm{mg}$ were smeared for direct microscopic detection. All samples were processed using five standard stool examination methods: iodine-stained smear for protozoal intestinal cysts, modified Kato-Katz thick smear (a semi-quantitative stool examination technique for detection of helminthic ova) $(6,7)$, simple saline smear for intestinal protozoa trophozoites, a test tube filter paper culture method for detection of hookworm larvae (Ancylostoma duodenale and Necator americanus), and adhesive cellophane tape anal swab method for Enterobius vermicularis in children aged less than 12 years old. Stool specimens were initially read by two separate examiners, and reviewed by a third examiner if there was disagreement.

\section{Statistical analysis}

Standard statistical methods for categorical data were used. The significance level was $\mathrm{P}<0.05$, and the calculation of $95 \% \mathrm{CIs}$ followed standard methods.

\section{RESULTS}

Fecal specimens were provided by 2558 of the 2648 participants $(96.6 \%)$. Parasites were identified in 1323 of these 2558 samples $(51.7 \%$, 95\% CI 35.02\% to 68.42\%). There were 934 subjects with only one parasite $(36.5 \%), 311$ with two $(12.2 \%), 76$ with three $(3.0 \%)$ and two with four $(0.08 \%)$ (Table 1). The most common parasites were Ascaris lumbricoides, followed by hookworm (A duodenale or N Americanus) and Trichurias trichuria (Table 1).

The prevalence of parasites was higher in residents of the four rural communities (421 of 506 subjects [83.2\%], 280 of 510 
subjects [54.9\%], 194 of 515 subjects [37.7\%] and 288 of 514 subjects [56\%]) than in the urban residents (140 of 513 subjects [27.3\%]) $(\mathrm{P}<0.01)$. Parasites were also significantly more frequent in women (976 of 1349 [72.4\%]) than in men (813 of $1209[67.3 \%])(\mathrm{P}<0.05)$. When stratified by type of parasite, this sex variation was consistent only for Ascaris species. The highest rates were observed in persons aged 15 to 19 years, and more than 80 years $(\mathrm{P}<0.01)$. Prevalence rates in preschool and primary school groups were higher than in other educational groups, although T trichuria was less common in preschool children than in primary school students (4.41\% versus $8.9 \%)$ $(\mathrm{P}<0.01)$. There were also significant differences in the prevalence rates among geographic and income groups $(\mathrm{P}<0.01)$. Ancylostoma species and whipworm were identified significantly less often in labourers, officers, students and children than in farmers $(\mathrm{P}<0.01)$ (Table 2). Ancylostoma species and T trichuria were more common in people, usually farmers who lived in hilly terrains (371 of 1535 [24.2\%] and 177 of 1535 [11.5\%] respectively) than in people from mountainous areas (79 of 510 subjects [15.5\%] and 21 of 510 subjects [4.1\%] respectively) or urban plains (three of 513 [0.6\%] and 13 of 513 [2.5\%], respectively) $(\mathrm{P}<0.01)$.

\section{DISCUSSION}

Enteric parasites are common in this rural district of China. About one-half of the population had positive stool specimens, although the majority had only a single parasite identified. Ascaris species, Ancylostoma species and whipworm were the most common organisms. This is consistent with previous reports from rural China $(4,5)$ and other developing countries (8-10). Most infections are asymptomatic, but roundworm infection may cause intestinal and respiratory symptoms, and is a cause of protein-energy malnutrition in undernourished children. Hookworm infection can cause anemia and hypoproteinemia (8). Multiple parasite infestations may not be independent because physiological, immunological or ecological factors that favour parasite infection may be specific to an individual (11).

The prevalence rate in females was significantly higher than in males. Sex-specific differences have been suggested to be due to differences in parasite susceptibility between the sexes (12), perhaps due to the influence of sex hormones (13). Some parasitologists suggest that susceptibility to parasitic infections is greater in males and may contribute to malebiased mortality (14). The present study, however, found a higher prevalence of parasitic infestation in women. The infection rate of female foreign workers in northern Taiwan was also reported to be 3 -fold higher than that of males (15). A major contributor to parasitic diseases in the developing world is inadequate water and sanitation. Obtaining water for houshold use in most rural areas is done by women, and women spend more time actually working in the water, washing clothes and cooking. This increases exposure to waterborne diseases and may explain the increased prevalence observed in women (16).

Two species, roundworm and hookworm, were detected in all age groups. However, the infection rates did not correlate with increased age - rates were highest in the groups aged 15 to 19 years and over 80 years, and lowest in the groups aged 30 to 39 years and 70 to 79 years. Children may have higher rates of infection because of greater exposure, while the elderly may have greater rates of infection because of an age-associated
TABLE 2

Parasitic infections and occupation in Beibei, China

\begin{tabular}{lclll}
\hline & & \multicolumn{3}{c}{$\begin{array}{c}\text { Infectious rates (positive } \\
\text { population / tested population) }\end{array}$} \\
\hline Occupation & $\begin{array}{l}\text { Tested } \\
\text { population }\end{array}$ & Ascarid & Ancylostoma & $\begin{array}{l}\text { Trichuris } \\
\text { trichiura }\end{array}$ \\
\hline Farmer & 1588 & $707 / 1588$ & $382 / 1588$ & $141 / 1588$ \\
& & $44.51 \%$ & $24.1 \%$ & $8.9 \%$ \\
Worker & \multirow{2}{*}{306} & $71 / 306$ & $1 / 306$ & $10 / 306$ \\
& & $23.2 \%$ & $0.33 \%$ & $3.3 \%$ \\
Student & \multirow{2}{*}{329} & $137 / 329$ & $45 / 329$ & $38 / 329$ \\
& & $41.6 \%$ & $13.7 \%$ & $11.6 \%$ \\
Child & 272 & $126 / 272$ & $24 / 272$ & $18 / 272$ \\
& & $46.31 \%$ & $8.8 \%$ & $6.6 \%$ \\
Officer & \multirow{2}{*}{63} & $19 / 63$ & $1 / 63$ & $4 / 63$ \\
& & $30.2 \%$ & $1.6 \%$ & $6.4 \%$ \\
Total & \multirow{2}{*}{2558} & $1060 / 2558$ & $453 / 2558$ & $211 / 2558$ \\
& & $41.4 \%$ & $17.7 \%$ & $8.3 \%$ \\
\hline
\end{tabular}

decline in their immune systems (17). The prevalence of infection is higher and occurs at a younger age when the transmission rate is high. When the transmission rate is low, the peak prevalence is lower and occurs at an older age - a 'peak shift' (18). Our observations would be consistent with a lower rate of transmission.

The prevalence of infestations in farmers was 8.3-fold higher than in all other occupational groups. Traditional life and farm labour practices, including irrigation and inappropriate fecal disposal, increase parasitic infectious risk in rural areas (19). The infection rate for farmers living in hilly terrains was higher than in mountainous areas. Disposal of human excreta is inadequate in some rural areas. In hilly land, sewage flows or leaks more easily to wells. Water drains more rapidly in mountainous areas, perhaps reducing infection rates. A recent World Health Organization report estimates that over 700 million Chinese people drink water contaminated with levels of animal and human waste exceeding government standards for safe water (28). The rates we observed were lower with increased education levels, similar to observations from Shanghai, China (21), although not all reports have confirmed this (10). The infectious rates were not, however, significantly associated with income.

Direct microscopy is widely used for the diagnosis of parasitic infections. Serial simple stool examinations may be a suitable method to detect pathogenic intestinal parasites. Only single samples were obtained for the present study, which may have underestimated the infection rates. Other, more sensitive and rapid techniques, such as polymerase chain reation (22), latex agglutination tests (23), serologic and intradermal tests (24), antigen detection tests and parasitic test kits $(25,26)$ were not used. Though the direct microscopy approach needs experienced microscopists and is labour intensive and time consuming for accurate diagnosis, the procedure is relatively cheap and applicable for the diagnosis of parasitic infections in developing countries.

In 1990, major parasitic diseases were estimated to account for $11.7 \%$ of the disease burden from communicable diseases. In many nations, parasitic infections are the most frequent causes of disease attributed to contaminated drinking water. Parasitic cysts are resistant to chlorination and require water 
filtration for removal, and the number of cysts required for infection may be very small (27). Thus, preventing drinking water contamination at the source is important in limiting transmission of these parasites (28). Improving private wells, based on national or provincial drinking water standards, and establishing safe public drinking water systems in rural areas may decrease parasitic density. Appropriate health education and management, and the improvement of toilets and stool disposal or personal hygiene, are also important to control parasitic infestations.

\section{CONCLUSIONS}

The present study reports a high prevalence of enteric parasites in one area of West China. The study demonstrates the usefulness of fecal examinations in developing countries, particularly in rural areas, because these examinations are easily performed

\section{REFERENCES:}

1. CDC. Global, infectious and parasitic diseases continue to threaten world health. AIDS Weekly Plus Aug 11, 1997;20-2. (Lett)

2. Herwaldt BL. Laboratory-acquired parasitic infections from accidental exposures. Clin Microbiol Rev 2001;14:659-88.

3. Charron DF. Potential impacts of global warming and climate change on the epidemiology of zoonotic diseases in Canada. Can J Public Health 2002;93:334-5.

4. Yu SH, Xu LQ, Jiang ZX, et al. Nationwide survey of human parasite in China. Southeast Asian J Trop Med Public Health 1994;25:4-10.

5. Xu L, Jiang Z, Yu S, et al. [Characteristics and recent trends in endemicity of human parasitic diseases in China]. Zhongguo Ji Sheng Chong Xue Yu Ji Sheng Chong Bing Za Zhi 1995;13:214-7.

6. Hassan MM, Matar MA, Mowafy N, et al. Dot ELISA for measuring anti-Fasciola IgG isotypes among patients with fascioliasis. J Egypt Soc Parasitol 2002;32:571-8

7. Kongs A, Marks G, Verle P, Van der Stuyft P. The unreliability of the Kato-Katz technique limits its usefulness for evaluating $S$ mansoni infections. Trop Med Int Health 2001;6:163-9.

8. Ananthakrishnan S, Nalini P, Pani SP. Intestinal geohelminthiasis in the developing world. Natl Med J India 1997;10:67-71.

9. Al-Shammari S, Khoja T, El-Khwasky F, Gad A. Intestinal parasitic diseases in Riyadh, Saudi Arabia: Prevalence, sociodemographic and environmental associates. Trop Med Int Health 2001;6:184-9.

10. Pitisuttithum P, Migasena S, Juntra A, Supeeranond L, Naksrissuk S. Socio-economic status and prevalence of intestinal parasitic infection in Thai adults residing in and around Bangkok metropolis. J Med Assoc Thailand 1990;73:522-5.

11. Howard, SC. Methods for estimation of associations between multiple species parasite infections. Parasitology 2001;122:233-51.

12. Baldock FC, Arthur RJ. A survey of fascioliasis in beef cattle killed at abattoirs in southern Queensland. Aust Vet J 1985;62:324-6.

13. Remoue F. Functional specific binding of testosterone to Schistosoma haematobium 28-kilodalton glutathione S-transferase. Infect Immun 2002;70:601-5.

14. Owens PF. Sex differences in mortality rate. Science 2002;297:2008-9.

15. Fan PC, Chung WC, Chen ER. Current status of imported parasitic infection among foreign workers in northern Taiwan (1999-2000). at a low cost. Monitoring the prevalence of enteric parasites may be useful in assessing the effectiveness of public health interventions, particularly improvement in drinking water quality.

Mr Nian Ji Luo was responsible for the detection of parasites and for administration of the study.

ACKNOWLEDGEMENTS: The cross-sectional study was kindly supported by grants from Beibei Health and Anti-epidemic Station (Center for Disease Control and Prevention, Beibei, Chongqing, China) and made possible through the cooperation of doctors and nurses in the town hospitals. The assistance of Hou Ji Wang, Zhao Chong Liu, Jia Rui Song, Li Ping Jiang, Xian Jie Tang, Chong Yu Pu, and Mei Zhang at the Health and Antiepidemic Station is acknowledged.

Kaohsiung J Med Sci 2001;17:503-8.

16. Womenaid International. Women are traditional water providers. $<$ http://www.womenaid.org/press/info/development/womenproviders. html> (Version current at May 12, 2003).

17. Albright JW, Albright JF. Ageing alters the competence of the immune system to control parasitic infection. Immunol Lett 1994;40:279-85.

18. Woolhouse MEJ. Patterns in parasite epidemiology: The peak shift. Parasitol Today 1998;14:428-34.

19. Kloos H, DeSole G, Lemma A. Intestinal parasitism in seminomadic pastoralists and subsistence farmers in and around irrigation schemes in the Awash Valley, Ethiopia, with special emphasis on ecological and cultural associations. Soc Sci Med 1981;15B:457-69.

20. Gai L, Ma X, Fu Y, Huang D. [Relationship between the rate of parasitic infection and the knowledge of prevention]. Zhongguo Ji Sheng Chong Xue Yu Ji Sheng Chong Bing Za Zhi 1995;13:269-72.

21. Beach M. Chinese government tackles environmental hazards. Lancet 2001;357:1024

22. Morgan UM, Thompson RCA. Molecular detection of parasitic protozoa. Parasitology 1999;117:73-85.

23. Robert R. Rapid tests for diagnosis of parasitic and fungal diseases. Immunoanalyse et Biologie Specialisee 1997;12:232-40.

24. Bruckner DA. Serologic and intradermal tests for parasitic infections. Pediatr Clin North Am 1985;32:1063-75.

25. DPCX. Diagnostic Producedures for stool specimens - Detection of parasitic antigens.

$<$ www.dpd.cdc.gov/dpdx/HTML/DiagnosticProcedures.asp?body= Frames/DiagnosticProcedures/body_dp_stoolpara_antigens.htm> (Version current at May 15, 2003).

26. Singh B. Molecular Methods for Diagnosis and Epidemiological Studies of Parasitic Infections. Int J Parasitol 1997;27:1135-45.

27. Water filters and parasitic diseases. Waterborne parasitic diseases. $<$ http://www.water-filters-r-us.com/Water-Filters-Parasitic.htm> (Version current at May 12, 2003).

28. US Environmental Protection Agency. Source water protection. $<$ http://www.epa.gov/safewater/protect.html > (Version current at May 12, 2003). 


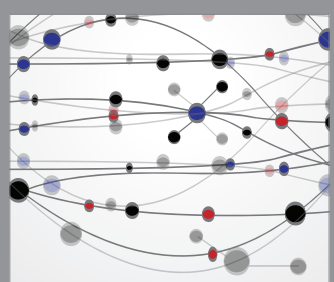

The Scientific World Journal
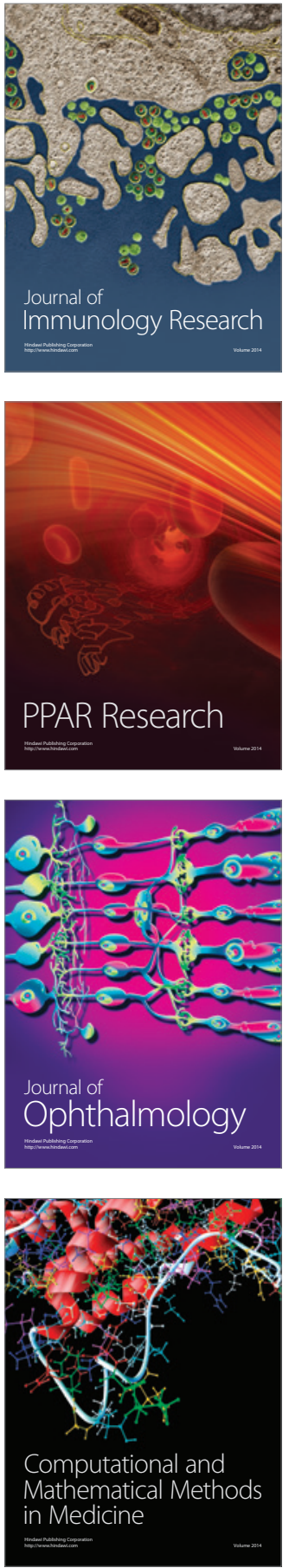

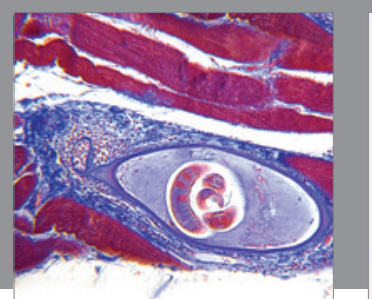

Gastroenterology Research and Practice

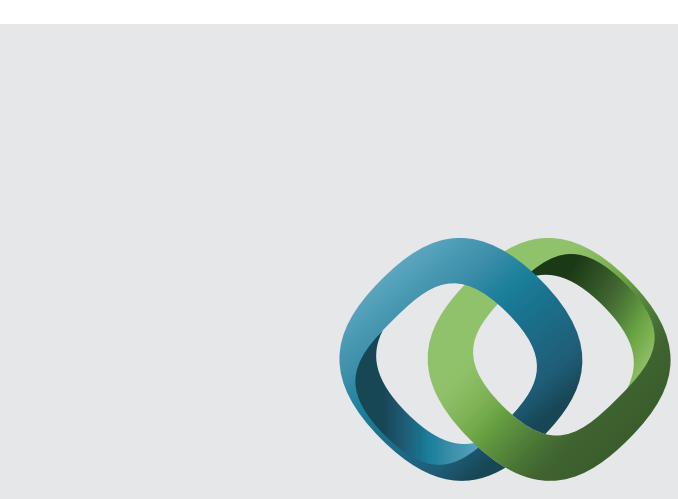

\section{Hindawi}

Submit your manuscripts at

http://www.hindawi.com
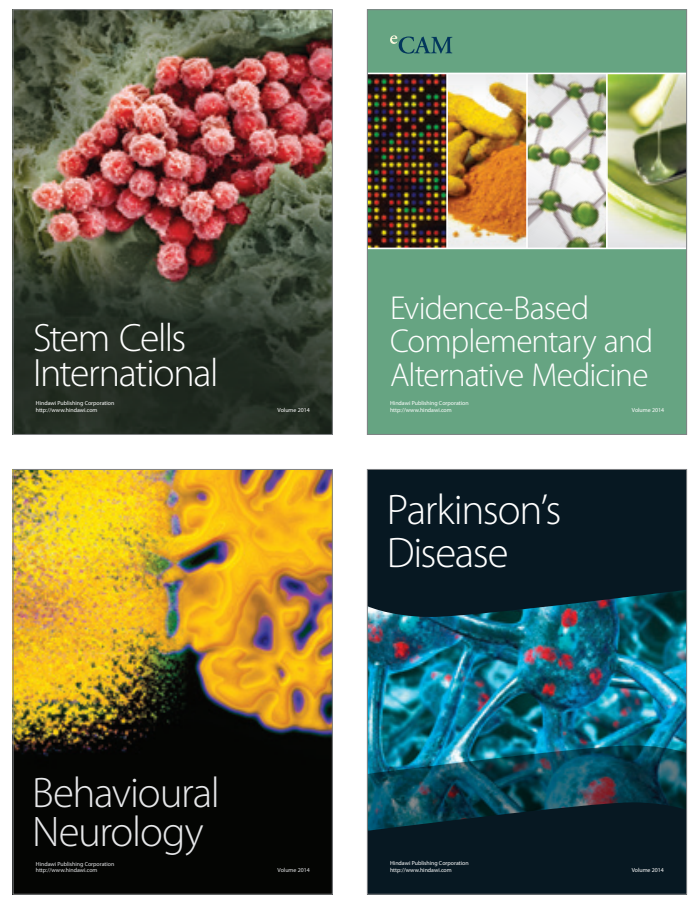
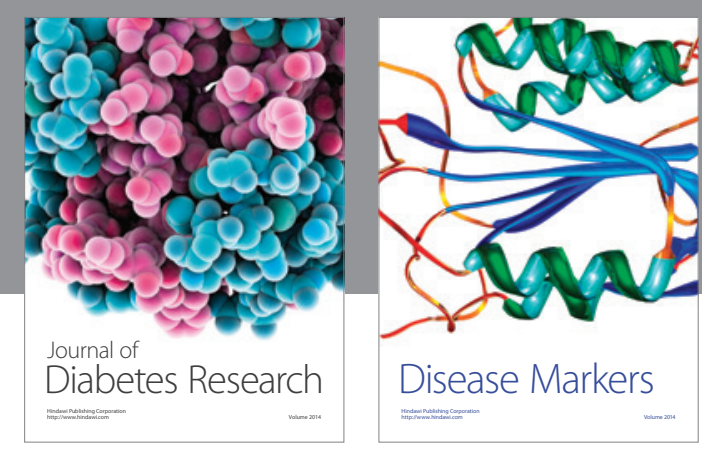

Disease Markers
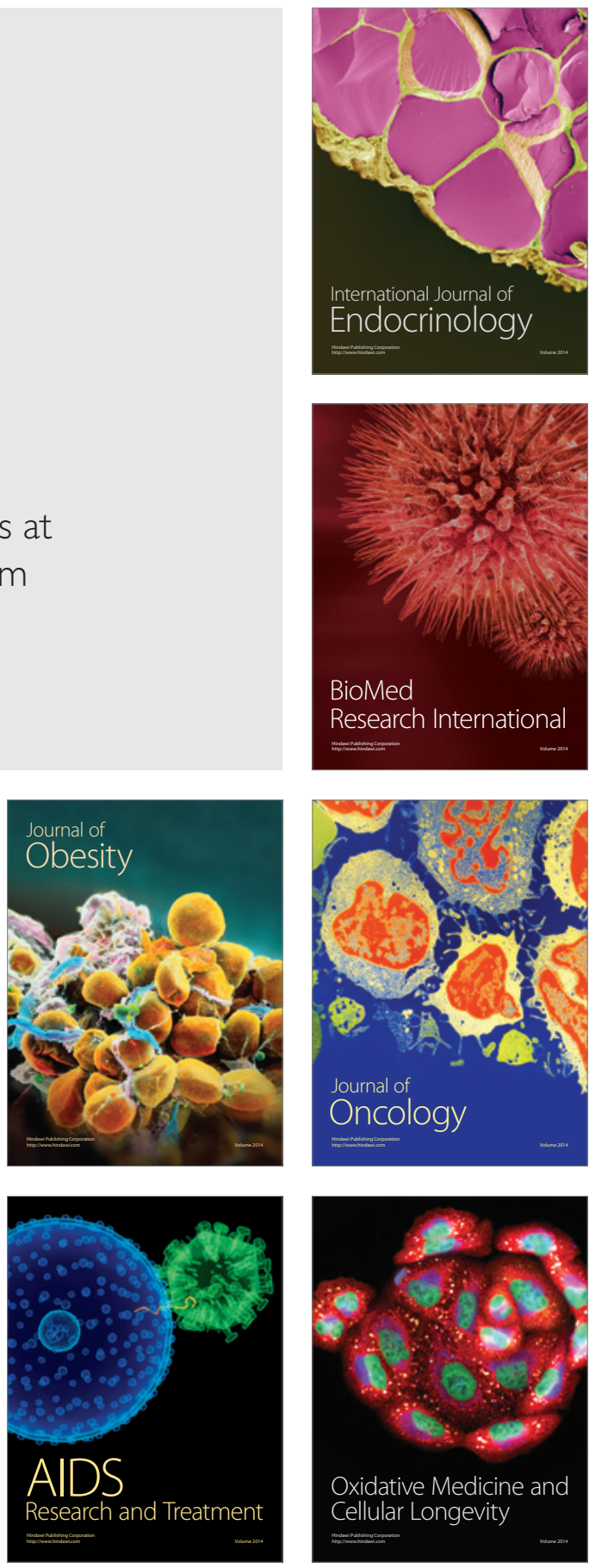